\title{
Secretomic analysis of large cell lung cancer cell lines using two-dimensional gel electrophoresis coupled to mass spectrometry
}

\author{
Zahra Yousefi ${ }^{1}$, Jamal Sarvari ${ }^{1,2,3}$, Kazuyuki Nakamura ${ }^{3}$, Yasuhiro Kuramitsu', \\ Abbas Ghaderi ${ }^{1}$, Zahra Mojtahedi ${ }^{1}$ \\ ${ }^{1}$ Cancer Proteomics and Biomarkers Lab, Shiraz Institute for Cancer Research, School of Medicine, \\ Shiraz University of Medical Sciences, Shiraz, Iran \\ ${ }^{2}$ Department of Virology, Shiraz University of Medical Sciences, Shiraz, Iran \\ ${ }^{3}$ Department of Biochemistry and Functional Proteomics, Yamaguchi University Graduate \\ School of Medicine, Yamaguchi, Japan
}

\begin{abstract}
The secretome of cancer cells is a valuable source of biomarkers that can ultimately reach the serum or other body fluids. Cancer biomarkers can facilitate early diagnosis and monitoring of the disease, contribute to our understanding of tumor biology, and support the development of more efficient therapies. Recently, high-throughput proteomic analysis of the conditioned media of cancer cell lines has shown potential to identify novel biomarkers in cancer. We used two-dimensional gel electrophoresis coupled to liquid chromatography tandem mass spectrometry to identify the secretome of the large cell lung cancer cell lines QU-DB and Mehr-80, which were established from a Canadian and a Persian patient, respectively. A total of 130 distinct protein species were identified. Most of them were previously found in serum or other body fluids, the membrane compartment or conditioned media of other cancer cell lines. Some of the proteins that we identified, e.g. IL-6, triosephosphate isomerase, PGP9.5, $\alpha$-enolase, Dickkopf-1, and peroxiredoxin-1 have been already known as putative serum markers for lung cancer, whereas others might be candidate markers for further validation in lung cancer body fluids such as IL-25, stathmin, vimentin, peptidyl-prolyl cis-trans isomerase A, transgelin-2, and chloride intracellular channel protein 4. (Folia Histochemica et Cytobiologica 2012, Vol. 50, No. 3, 368-374)
\end{abstract}

Key words: biomarkers, lung cancer cell lines, conditioned media, mass spectrometry, secretome

\section{Introduction}

Cancer cell communications are substantially influenced by their secretome, a collection of molecules that are shed (membrane and membrane-bound proteins) or secreted either through classical (proteins with a signal peptide) or nonclassical (intracellular proteins) pathways. The identification of cancer cell

Correspondence address: Z. Mojtahedi,

Shiraz Institute for Cancer Research,

Shiraz University of Medical Sciences,

Postal code: 71348-45748, Shiraz, Iran;

tel.: + 98711230 3687, fax: +98 7112304952 ,

e-mail:mojtahedizahra@hotmail.com secretome has uncovered mechanisms related to angiogenesis, invasion and metastasis, and can contribute to the development of new strategies for the efficient control of cancer. Moreover, secreted or shed proteins can reach body fluids including serum, an ideal sample source for early diagnosis and monitoring of cancer [1-3].

The mortality rate is still high in lung cancer. Novel lung cancer serum biomarkers are needed, because those identified to date, such as cancer embryonic antigen and squamous cell carcinoma (SCC) antigen, lack sufficient specificity and sensitivity to serve as an efficient biomarker [1].

Although serum contains tumor markers, masking low abundant proteins by high abundant albumin 
and globulins makes serum high-throughput analysis unreliable. To overcome this drawback, proteomic identification of conditioned media of cancer cell lines has recently attracted much attention [1-3]. Generally, the identified proteins were already known to be involved in cancer development and progression, and subsequent studies validated the presence of several of them in sera from cancer patients. For example, more than 1,000 proteins in conditioned media from four lung cancer cell lines of different histological backgrounds (small-cell lung cancer H1688, adenocarcinoma line H23, SCC cell line H520, and large cell lung carcinoma (LCC) line H460) have been identified. Using different search tools, the most promising candidates for validation in sera were then selected, and increased levels of some of them were confirmed in sera of lung cancer patients [1].

Based on the size and appearance of the malignant cells, lung cancers are divided into small cell lung carcinoma (SCLC) and non-small cell lung carcinoma (NSCLC); the latter type accounts for more than $80 \%$ of all lung tumors [1]. Among the three major subtypes of NSCLC (adenocarcinoma, SCC and LCC), LCC (9\% of all lung cancers) has the poorest prognosis. This poorly differentiated lung cancer consists of large cells with abundant cytoplasm and large nuclei. The neuroendocrine variant of LCC has the worst prognosis $[4,5]$.

The secretome of two established LCC cell lines QU-DB and Mehr-80 have not been investigated to date. Cell line QU-DB was established from a primary lung tumor of a 70 year-old man with LCC in Canada, and Mehr-80, a neuroendocrine variant of LCC, was established from the pleural effusion of a 40 year-old woman in Iran $[4,5]$. To find novel lung cancer biomarkers, the present study analyzed the conditioned media of the two LCC cell lines using two-dimensional gel electrophoresis (2DE) coupled to mass spectrometry (MS).

\section{Material and methods}

Cell culture and preparation of conditioned media. The study was approved by the Ethics Committee of Shiraz University of Medical Sciences. The QU-DB and Mehr-80 LCC cells were purchased from the Pasteur Institute of Iran. They were cultured in $150 \mathrm{~cm}^{2}$ flasks (Nunc, Roskilde, Denmark) at $37^{\circ} \mathrm{C}$ (5\% $\mathrm{CO}_{2}$ and 95\% air) in RPMI-1640 (Biosera, Ringmer, UK) plus $10 \%$ FBS (Biosera), and $100 \mathrm{U} / \mathrm{mL}$ penicillin with $100 \mu \mathrm{g} / \mathrm{mL}$ streptomycin (Biosera) until they reached 70 $-80 \%$ confluence. The media were then discarded, and the cells washed three times with PBS and incubated in $30 \mathrm{~mL}$ RPMI with $8 \mathrm{mM}$ L-glutamine (Sigma-Aldrich, Steinheim, Germany) for another $24 \mathrm{~h}$. The media were collected and centrifuged at $4^{\circ} \mathrm{C}(200 \times \mathrm{g}, 10 \mathrm{~min})$ to remove debris, followed by sterile filtration by cell culture filters (JET BIO-
FIL, Guangzhou, China) with a $0.2 \mu \mathrm{m}$ pore size. The collected media were frozen at $-80^{\circ} \mathrm{C}$ until use. The cell viability was checked by the trypan blue dye exclusion method.

Each cell line was grown in six batches with $30 \mathrm{~mL}$ serum-free medium. Two 30-mL batches were combined for each cell line, then a protease inhibitor cocktail (Roche, Penzberg, Germany) was added to a $1 \times$ final concentration, and the mixture was dialyzed overnight at $4^{\circ} \mathrm{C}$ using a 3.5-kDa molecular mass cutoff membrane in $10 \mathrm{~L}$ of $1 \mathrm{mM}$ ammonium bicarbonate buffer (Sigma) with four solution changes. The dialyzed media were frozen and lyophilized to dryness. Three lyophilized samples per cell line were obtained from the three combinations of two $30-\mathrm{mL}$ portions of media. To prepare the media to be used as a negative control, the above procedure was repeated with the culture media without cells.

After lyophilization, the samples were resuspended in lysis buffer ( $7 \mathrm{M}$ urea, $2 \mathrm{M}$ thiourea, 4\% CHAPS, $2 \%$ immobilized pH gradient (IPG) buffer (pH3-10) (GE Healthcare, Uppsala, Sweden)), aliquoted and stored at $-80^{\circ} \mathrm{C}$. The protein concentration was determined by the Bradford protein method and bovine serum albumin (Sigma, Germany) as standard.

Two-dimensional gel electrophoresis. The first dimensional isoelectric focusing (IEF) was done with the Protean IEF cell system (Bio-Rad, Philadelphia, PA, USA). Approximately $250 \mu \mathrm{g}$ of the protein sample was applied per IPG strip ( $\mathrm{pH} \mathrm{3-10} \mathrm{nonlinear,} 18 \mathrm{~cm}$ ) by active rehydration $(50 \mathrm{~V}, 20 \mathrm{C})$ for $14 \mathrm{~h}$ in rehydration buffer $(2 \mathrm{M}$ thiourea (Merck, Darmstadt, Germany), $8 \mathrm{M}$ urea, $2 \%$ w/v CHAPS, $0.3 \% \mathrm{wt} / \mathrm{vol}$ DTT, $2 \%$ vol/vol IPG 3-10 buffer and bromophenol blue) followed by IEF for a total of $90,000 \mathrm{Vh}$.

After IEF, each strip was equilibrated in $10 \mathrm{~mL}$ equilibration buffer (50 mM Tris, $\mathrm{pH} 8.8,6 \mathrm{M}$ urea, 30\% wt/vol glycerol, $2 \% \mathrm{wt} / \mathrm{vol}$ SDS) containing $65 \mathrm{mM}$ DTT (fist step) and $135 \mathrm{mM}$ idoacetamide (second step) at room temperature for $15 \mathrm{~min}$. Then the equilibrated strips were sealed on the top of two-dimensional $12 \%$ polyacrylamide gels with a Protean II xi 2-D Cell (Bio-Rad) at $15 \mathrm{~mA} / \mathrm{gel}$ for $10 \mathrm{~min}$ and then $25 \mathrm{~mA} /$ gel until the bromophenol blue dye front reached the bottom of the gels. The gels were visualized with an analytical silver staining technique, scanned with a GS-800 calibrated densitometer (Bio-Rad) and analyzed with Prodigy SameSpots version 1.0 software (Nonlinear Dynamics, Newcastle, UK) according to the manufacturer's instructions. The reagents were purchased from GE Healthcare, Uppsala, Sweden, except where stated.

\section{Liquid chromatography-mass spectrometry (LC-MS/MS).} The spots of interest were picked up from gels that were stained with a preparative MS-compatible silver staining method. For in-gel digestion of proteins, the spots were destained, reduced, alkylated, and finally digested with sequencing grade modified trypsin (Promega, Madison, WI, USA). The resulting peptides were extracted, and lyo- 
philized using a vacuum drier. Lyophilized samples were resuspended in $0.1 \%$ formic acid (FA) prior to LC-MS/MS analysis. An Agilent 1100 LC/MSD trap XCT was used for HPLC and MS/MS. Solutions used were water $/ 0.1 \% \mathrm{FA}$ and ACN/0.1\% FA. A trap column (G 1375-87320, 105 mm, $25 \mu \mathrm{m}$; Agilent, Germany) was connected to a standard column (Zorbax 300 SB-C18, $3.5 \mu \mathrm{m}, 0.3 \times 75 \mathrm{~mm}$ ). Peptides $(12 \mu \mathrm{l})$ were loaded on a trapping column and desalted. The elution program was $2-60 \%$ B for $55 \mathrm{~min}, 80 \%$ B for $8 \mathrm{~min}$ and re-equilibration of $2 \% \mathrm{~B}$ for $10 \mathrm{~min}$, for a total run of $78 \mathrm{~min}$. The MS was operated in standard scan mode for MS analysis and in ultra scan mode for MS/MS analysis. The MS/MS data was analyzed with the Spectrum Mill database search engine (Agilent, Palo Alto, CA, USA) against the Swiss-Prot database (released May, 2010).

\section{Results}

We used 2DE and LC-MS/MS to identify proteins in the conditioned media of the LCC cell lines QU-DB and Mehr-80. To reduce the likelihood of intracellular protein contamination, the secretome were collected from 24-h serum-free culture media because the trypan blue exclusion test showed a low rate of cell death (less than $2 \%$ ) over $24 \mathrm{~h}$. Three gels were run for each cell line, and the similarity of gels was found to be more than $80 \%$. Collectively, 395 reproducible, distinct, intense spots were excised from all gels. Of these 395 spots, 141 were found in the conditioned media of both cell lines, of which 116 were identified by MS. For 96 of the 116 spots, MS was done in just one cell line, but for 20 of them (spots $2-4,24,25,29,34$, and 35 in Table 1, and 64, 65, 68, $86,100,102,112,115,116,132-134$ in Supplementary File 1), MS was done in both cell lines to establish that spots with the same position in gels from each cell line represented the same polypeptide. Seventytwo of the 395 spots were hardly-visible/invisible on Mehr-80 gels, and 41 were hardly-visible/invisible on QU-DB gels. Of these unique spots, 39 were identified by MS analysis.

The identified proteins were related to 130 protein species that were essentially involved in protein folding, the cytoskeleton, signal transduction, cell growth, metabolism and redox regulation (Table 1 and Supplementary File 1). By searching in Swiss-Prot and published articles, the majority of proteins were found to have been previously detected in body fluids, the conditioned media of cancer cell lines, and/or related to the cell membrane in humans [1-35]. Each of these proteins was usually present in more than one of these locations. Of them, 38 were already found in serum or other body fluids in pathological conditions (Table 1). Their descriptions and positions on gels are displayed in Table 1 and Figure 1. Other proteins, which were essentially related to cell membrane/membrane-bound or common to those in prior publications on cancer cell secretome [3], are listed in Table 2 (Supplementary File 1).

\section{Discussion}

To identify candidate extracellular biomarkers for lung cancer, the conditioned media of QU-DB and Mehr-80 LCC cell lines were subjected to 2DE and MS analysis. Most of the 130 identified proteins were already found in body fluids/in vivo tumor microenvironment, conditioned media of other cancer cell lines, or related to the cell membrane in humans [1-35], the locations supporting the possibility that a protein might be secreted or shed. It is known that some intracellular proteins, particularly those with increased concentrations in body fluids, may be secreted by a variety of mechanisms such as exocytosis of secretory vesicles or exomes $[1,3,11]$. Despite optimized cell confluence and incubation times during media preparation, the presence of some of the intracellular proteins in conditioned media probably resulted from cell death.

Fifteen of the identified proteins in conditioned media of QU-DB and Mehr-80, e.g. IL-6, triosephosphate isomerase, PGP9.5, high mobility group protein B1, Dickkopf-1, and peroxiredoxin-1 were already known to be putative serum markers for lung cancer $[1,2,6-16]$. Twenty three of the identified proteins have been previously found in human body fluids or the in vivo tumor microenvironment in pathological conditions other than lung cancer (Table 1) [17-35], indicating that they might be products of cellular secretion. Among them, those known to be overexpressed in lung cancer such as $78-\mathrm{kDa}$ glucose-regulated protein [14], epidermal fatty acid-binding protein [36], transgelin-2 [37], hsp27 [38], stress-induced phosphoprotein 1 [38], vimentin [39], and transketolase [40] may be more appropriate candidate biomarkers for further validation in body fluids from lung cancer patients.

In the conditioned media of the QU-DB and Mehr-80, in addition to IL-6, we also found two members of the cytokine family with classical signal peptides for secretion: ILE1 and IL-25 [34, 35]. The former is associated with epithelial-to-mesenchymal transition and metastasis in breast cancer [34], whereas the latter is a mediator of type- 2 immune responses. Moreover, IL-25 was reported to have a pathogenic role in allergic lung diseases, and was up-regulated in nasal lavage fluid [35]. It has been shown that epithelial cells, myeloid cells, eosinophils, basophils and mast cells produce IL-25 [35], and its presence in conditioned media of several cancer cell lines including lung has recently been reported [3]. 
Table 1. Descriptions of the 38 proteins identified in conditioned media of QU-DB and Mehr- 80 lung cancer cell lines that have been previously reported in human body fluids in pathological conditions. Spots numbers are the same as those in Figure 1

\begin{tabular}{|c|c|c|c|c|c|c|}
\hline $\begin{array}{l}\text { Spot } \\
\text { no. }\end{array}$ & Protein name & $\begin{array}{c}\text { Predicted } \\
\text { pI/MW }\end{array}$ & Accession no ${ }^{\mathrm{a}}$ & $\begin{array}{c}\text { Score/numbers } \\
\text { of matched } \\
\text { peptides }\end{array}$ & Locations $^{b}$ & Function \\
\hline 1,2 & Peroxiredoxin-1 & $8.27 / 22.1$ & Q06830 & $55 / 5$ & Serum $[8]$ & Redox regulation \\
\hline 3,4 & Glutathione S-transferase P & $5.43 / 23.3$ & P09211 & $79 / 5$ & Serum [13] & Redox regulation \\
\hline 5 & High mobility group protein B1 & $5.61 / 24.8$ & P09429 & $129 / 10$ & Serum $[6]$ & Immune response \\
\hline 6,7 & Triosephosphate isomerase (TPI) & $6.45 / 26.6$ & P60174 & $377 / 23$ & Serum [12] & Metabolism \\
\hline 8,9 & $\alpha$-enolase & $7.01 / 47.1$ & P06733 & $160 / 11$ & Serum [7] & Metabolism \\
\hline 10 & Peroxiredoxin- 6 & $6 / 25$ & P30041 & $279.65 / 19$ & Serum [12] & Redox regulation \\
\hline 11 & $\begin{array}{l}\text { Superoxide dismutase }(\mathrm{Mn}) \text {, } \\
\text { mitochondrial }\end{array}$ & $8.34 / 24.7$ & P04179 & $72 / 5$ & Serum [2] & Redox regulation \\
\hline 12,13 & L-lactate dehydrogenase B chain & $5.71 / 36.6$ & P07195 & $249 / 17$ & Serum $[1]$ & Metabolism \\
\hline 14,15 & Dickkopf-related protein 1 & $8.8 / 28.6$ & O94907 & $79 / 5$ & Serum [9] & Signal transduction \\
\hline 16 & $\begin{array}{l}\text { Ubiquitincarboxyl-terminal } \\
\text { hydrolase isozyme L1(PGP9.5) }\end{array}$ & $5.33 / 24.8$ & P09936 & $85 / 7$ & Serum $[11]$ & Thiol protease \\
\hline 17 & Interkeukin-6 (IL-6) & $6.18 / 23.7$ & P05231 & $99 / 6$ & Serum $[10]$ & $\begin{array}{l}\text { Cytokine, } \\
\text { inflammatory } \\
\text { response }\end{array}$ \\
\hline 18,19 & Plasminogen activator inhibitor 1 & $6.67 / 45$ & P05121 & $289 / 19$ & Serum [2] & $\begin{array}{l}\text { Protease inhibitor/ } \\
\text { /metabolism }\end{array}$ \\
\hline 20 & $\begin{array}{l}\text { Isocitrate dehydrogenase } \\
\text { [NADP] cytoplasmic }\end{array}$ & $6.53 / 46.6$ & O75874 & $98 / 8$ & Serum $[16]$ & TCA cycle \\
\hline 21 & Phosphoglycerate kinase 1 & $8.3 / 44.6$ & P00558 & $267 / 18$ & Serum $[14]$ & Metabolism \\
\hline 22 & $\begin{array}{l}\text { Insulin-like growth } \\
\text { factor-binding protein } 2\end{array}$ & $7.48 / 35.1$ & P18065 & $109 / 7$ & Serum [15] & Signal transduction \\
\hline 23 & Protein FAM3C (ILE1) & $8.25 / 24.6$ & Q92520 & $46 / 3$ & $\begin{array}{c}\text { In vivo tumor } \\
\text { microenvironment } \\
{[34]}\end{array}$ & $\begin{array}{l}\text { Cytokine, signal } \\
\text { transduction }\end{array}$ \\
\hline 24 & $\begin{array}{l}\text { Chloride intracellular } \\
\text { channel protein } 1 \text { (CLIC1) }\end{array}$ & $5.09 / 26.9$ & O00299 & $79 / 6$ & Serum $[24]$ & Ion transport \\
\hline 25,26 & Protein DJ-1 & $6.33 / 19.8$ & Q99497 & $113 / 8$ & Serum $[23]$ & Protein folding \\
\hline 27 & L-lactate dehydrogenase A chain & $8.44 / 36.6$ & P00338 & $206 / 15$ & Serum [22] & Metabolism \\
\hline $28-31$ & $\begin{array}{l}\text { Glyceraldehyde-3-phosphate } \\
\text { dehydrogenase }\end{array}$ & $8.57 / 37.4$ & P04406 & $35 / 2$ & Serum $[18]$ & Metabolism \\
\hline 32,33 & $\begin{array}{l}\text { Protein disulfide-isomerase A3 } \\
\text { (ERp57) }\end{array}$ & $5.99 / 56.7$ & P30101 & $72 / 6$ & Serum $[20]$ & Protein folding \\
\hline 34 & $\begin{array}{l}\text { Stress-induced phosphoprotein } 1 \\
\text { (STIP1) }\end{array}$ & $6.4 / 62.6$ & P31948 & $250 / 18$ & Serum $[21]$ & Protein folding \\
\hline 35 & $\begin{array}{l}\text { Proteasome activator complex } \\
\text { subunit } 3 \text { (PSME3) }\end{array}$ & $5.6 / 29$ & P61289 & $83 / 5$ & Serum [19] & $\begin{array}{l}\text { Protein } \\
\text { degradation }\end{array}$ \\
\hline 36 & $78 \mathrm{kDa}$ glucose-regulated protein & $5.07 / 72.3$ & P11021 & $657 / 42$ & Serum [20] & Metabolism \\
\hline 37 & Heat shock 27 kDa protein (hsp27) & $5.98 / 22.7$ & P04792 & $45 / 4$ & Serum $[20]$ & Protein folding \\
\hline 38 & Vimentin & $5.06 / 53.6$ & P08670 & $52 / 3$ & Serum [17] & $\begin{array}{l}\text { Cell motility, } \\
\text { cytoskeleton }\end{array}$ \\
\hline 39 & Peroxiredoxin-4 & $5.86 / 30$ & Q13162 & $72 / 5$ & Serum $[25]$ & Redox regulation \\
\hline 40 & $\begin{array}{l}\text { Epidermal fatty acid-binding } \\
\text { protein (E-FABP) }\end{array}$ & $6.6 / 15.1$ & Q01469 & $20 / 1$ & Serum $[26]$ & Transport \\
\hline 41 & $\begin{array}{l}\text { Adenylyl cyclase-associated } \\
\text { protein-1 (CAP1) }\end{array}$ & $8.27 / 57$ & Q01518 & $32 / 2$ & Urine [27] & $\begin{array}{l}\text { Cell mobility, } \\
\text { cytoskeleton }\end{array}$ \\
\hline 42 & UPF0556 protein C19orf10 (IL-25) & $6.2 / 18.7$ & Q969H8 & $76 / 5$ & Nasal lavage [35] & $\begin{array}{c}\text { Signal } \\
\text { transduction }\end{array}$ \\
\hline
\end{tabular}


Table 1. cont.

\begin{tabular}{|l|l|c|c|c|c|c|}
\hline 43 & Inorganic pyrophosphatase & $5.54 / 32.6$ & Q15181 & $122 / 8$ & Serum [33] & Metabolism \\
\hline $44-47$ & Actin, cytoplasmic 2 & $5.31 / 41.7$ & P63261 & $79 / 6$ & Serum [28] & Cell motility \\
\hline 48 & Glutamine synthetase & $6.43 / 44.7$ & P15104 & $13.94 / 1$ & $\begin{array}{c}\text { Serum, } \\
\text { Cerebrospinal } \\
\text { fluid [31] }\end{array}$ & Metabolism \\
\hline 49 & Collagen alpha-1(III) chain & $6.21 / 138.5$ & P02461 & $88 / 6$ & $\begin{array}{c}\text { Extracellular } \\
\text { matrix [32] }\end{array}$ & $\begin{array}{c}\text { Cell-cell } \\
\text { interaction }\end{array}$ \\
\hline 50,51 & Retinol-binding protein 4 (RBP4) & $5.76 / 23$ & P02753 & $109 / 9$ & Serum [28] & Transport \\
\hline 52 & $\begin{array}{l}\text { Apolipoprotein A-I-binding } \\
\text { protein }\end{array}$ & $7.56 / 31.6$ & Q8NCW5 & $37 / 3$ & $\begin{array}{c}\text { Serum, } \\
\text { cerebrospinal } \\
\text { spinal fluid [29] }\end{array}$ & $\begin{array}{c}\text { Transport, } \\
\text { metabolism }\end{array}$ \\
\hline 53 & Transgelin-2 & $8.41 / 22.3$ & P37802 & $183 / 13$ & Serum [28] & Cell mobility \\
\hline 54 & Transketolase & $7.58 / 67.8$ & P29401 & $213 / 16$ & Serum [30] & Metabolism \\
\hline
\end{tabular}

aSwiss-Prot accession number; b Spots 1-22 were previously detected in lung cancer body fluids, 23-38 were detected in types of cancer other than lung cancer body fluids, and the rest in other diseases' body fluids
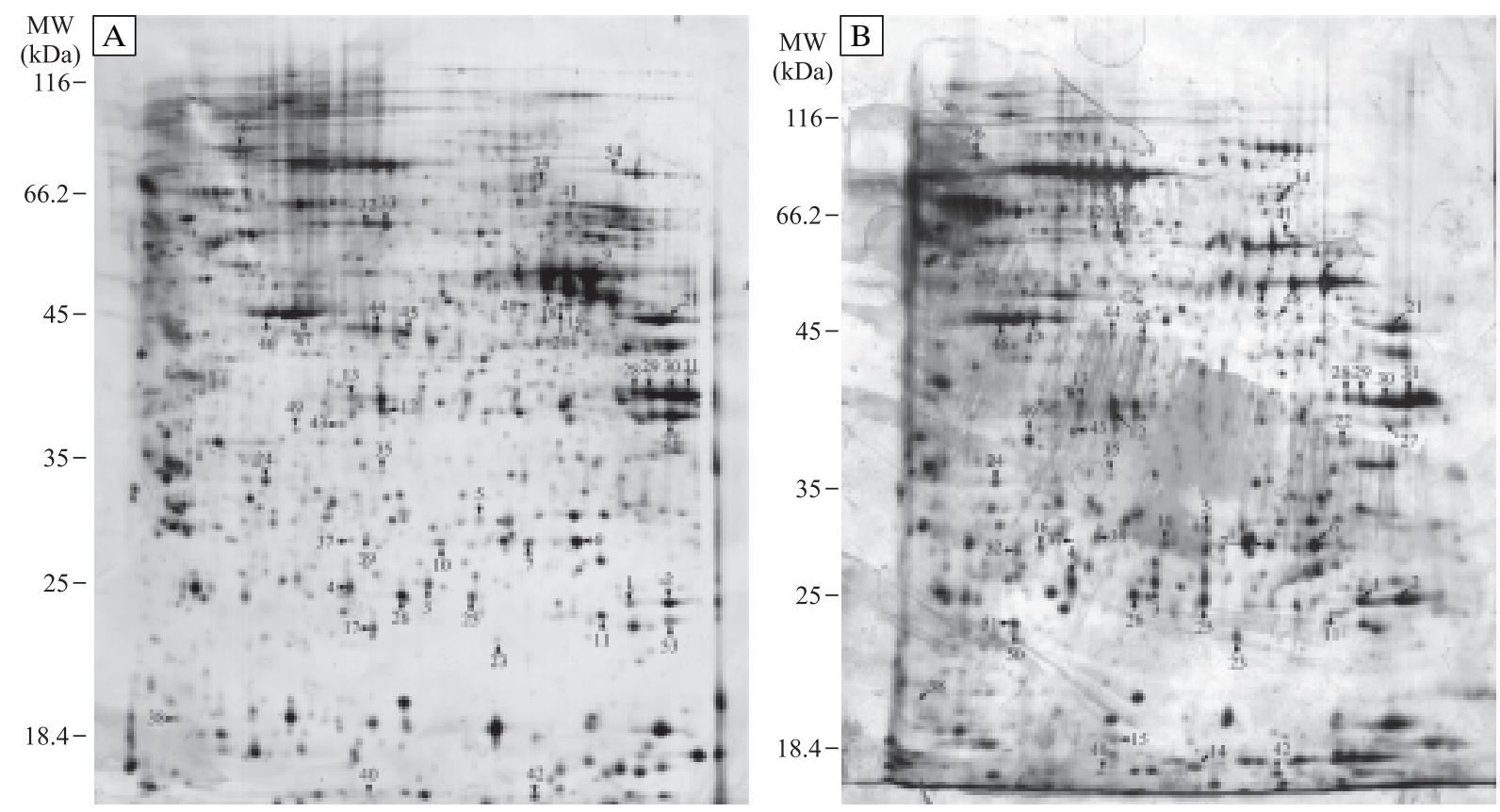

Figure 1. Proteome of Mehr-80 (A) and QU-DB (B) large-cell lung cancer cell lines were separated using 2DE with pH 3-10 nonlinear IPG strips and visualized by silver staining. The locations of the 54 spots in Table 1 are labeled with numbers. Spots 1-13, 21, 23-49 were observed in both QU-DB and Mehr-80 cell lines. Spots 14-16, 22 and 50-52 were invisible or hardly visible on Mehr-80 gels. Spots 17-20, 53 and 54 were invisible or hardly visible on QU-DB gels

Membrane/membrane-bound proteins can be released into body fluids and serve as valuable serum biomarkers, e.g. carcinoembryonic antigen in lung cancer [1]. Some of the proteins we have identified belong to this category. Examples of those which are overexpressed in lung cancer and which deserve further attention are annexin1 [14], T complex protein, [38] and transketokase [40].

Most of the proteins identified in this study have been reported to be present in media used to grow human cancer cell lines [1-3, 11]. Several of them, e.g. stathmin, are overexpressed in lung cancer. Stathmin provokes microtubule depolymerisation and regulates microtubule-dependent processes including cell division and motility. Its overexpression has been linked to cell migration and invasion in lung adenocarcinoma and SCC [41]. Glutathione S-transferase omega-1 [11], and chloride intracellular channel protein 4 (CLIC4) [11] have been found in lung cancer cell line media compared to media derived from nor- 
mal lung tissue cell cultures, and the search for these proteins in serum may be worthwhile.

It remains to be determined whether our candidate biomarkers are found in all types of lung cancer, or are restricted to LCC. Because NSCLC studies usually focus on SCC and adenocarcinoma, the current data is insufficient to judge their specificity to LCC. Among proteins identified in this study, lactate dehydrogenase-B, $\alpha$-enolase, IL-6, hsp-27, stress-induced phosphoprotein 1, plasminogen activator inhibitor 1, vimentin, T-complex protein 1, and isocitrate dehydrogenase 1 were investigated in LCC [10, $38,39,42]$. They were found to be significantly overexpressed in adenocarcinoma and SCC subtypes in addition to LCC. For vimentin and IL-6, there are reports to show their increases in LCC compared to other types of NSCLC [10, 39]. Vimentin, an intermediate filament protein, usually expressed in mesenchymal cells, plays a role in cell movement. Vimentin is a marker for epithelial to mesenchymal transition, a process that has been critically linked to cancer invasiveness [17]. Interestingly, the highest percentage of vimentin positivity has been observed in LCC compared to other subtypes of NSCLC (SCC and adenocarcinoma) and SCLC [39].

In conclusion, we searched for potential biomarkers of lung cancer in conditioned media from two lung cancer cell lines. Some of the identified proteins were already suggested as being putative serum biomarkers for lung cancer, i.e. PGP9.5 and IL-6. Others, such as IL-25, stathmin, vimentin, epidermal fatty acidbinding protein, transgelin-2, stress-induced phosphoprotein 1 and CLIC4, should be further investigated as possible biomarkers of LCC.

\section{Acknowledgements}

This work was funded by grants from the Shiraz University of Medical Sciences (Grant No. 87-4441) and the Shiraz Institute for Cancer Research (ICR-100$-503)$. No conflict of interest is declared.

\section{References}

1. Pavlou MP, Diamandis EP. The cancer cell secretome: A good source for discovering biomarkers? Proteomics. 2010;2:1-11.

2. Xue H, Lu B, Lai M. The cancer secretome: a reservoir of biomarkers. J Transl Med. 2008;6:52.

3. Wu CC, Hsu CW, Chen CD et al. Candidate serological biomarkers for cancer identified from the secretomes of 23 cancer cell lines and the human protein atlas. Mol Cell Proteomics. 2010;9:1100-1117.

4. Cole SP, Campling BG, Dexter DF, Holden JJ, Roder JC. Establishment of a human large cell lung tumor line (QUDB) with metastatic properties in athymic mice. Cancer. 1986;58:917-923.

5. Sharifzadeh S, Owji SM, Pezeshki AM et al. Establishment and characterization of a human large cell lung cancer cell line with neuroendocrine differentiation. Pathol Oncol Res. 2004;10:225-230.

6. Naumnik W, Nilklińska W, Ossolińska M, Chyczewska E. Serum levels of HMGB1, survivin, and VEGF in patients with advanced non-small cell lung cancer during chemotherapy. Folia Histochem Cytobiol. 2009;47:703-709.

7. Zhang Y, Li M, Liu Y, Han N, Zhang K, Xiao T et al. [ENO1 protein levels in the tumor tissues and circulating plasma samples of non-small cell lung cancer patients]. Zhongguo Fei Ai Za Zhi. 2010;13:1089-1093.

8. Chang JW, Lee SH, Jeong JY et al. Peroxiredoxin-I is an autoimmunogenic tumor antigen in non small cell lung cancer. FEBS Lett. 2005;597:2873-2877.

9. Sheng SL, Huang G, Yu B, Qin WX. Clinical significance and prognostic value of serum Dickkopf-1 concentrations in patients with lung cancer. Clin Chem. 2009;55:1656-1564.

10. Katsumata N, Eguchi K, Fukuda M et al. Serum levels of cytokines in patients with untreated primary lung cancer. Clin Cancer Res. 1996;2:553-559.

11. Kim JE, Koo KH, Kim YH, Park YG. Identification of potential lung cancer biomarkers using an in vitro carcinogenesis model. Exp Mol Med. 2008;40:709-720.

12. Zhang $\mathrm{XZ}$, Xiao ZF, Li C et al. Triosephosphate isomerase and peroxiredoxin 6, two novel serum markers for human lung squamous cell carcinoma. Cancer Sci. 2009;100:2396-2401.

13. Hida T, Kuwabara M, Ariyoshi $Y$ et al. Serum glutathione S-transferase-pi level as a tumor marker for non-small cell lung cancer. Potential predictive value in chemotherapeutic response. Cancer. 1994;73:1377-1382.

14. Chen G, Gharib TG, Wang $\mathrm{H}$ et al. Protein profiles associated with survival in lung adenocarcinoma. Proc Natl Acad Sci USA. 2003;100:13537-13542.

15. Yazawa T, Sato $H$, Shimoyamada $H$ et al. Neuroendocrine cancer-specific up-regulating mechanism of insulin-like growth factor binding protein-2 in small cell lung cancer. $\mathrm{Am}$ J Pathol. 2009;175:976-987.

16. Tan $\mathrm{F}$, Jiang $\mathrm{Y}$, Sun $\mathrm{N}$ et al. Identification of isocitrate dehydrogenase 1 as a potential diagnostic and prognostic biomarker for non-small cell lung cancer by proteomic analysis. $\mathrm{Mol}$ Cell Proteomics. 2012;11:M111.008821.

17. Sun S, Poon RT, Lee NP, Yeung C, Chan KL, Ng IO et al. Proteomics of hepatocellular carcinoma: serum vimentin as a surrogate marker for small tumors $(<$ or $=2 \mathrm{~cm})$. J Proteome Res. 2010;9:1923-1930.

18. Shibuya A, Ikewaki N. High serum glyceraldehyde-3-phosphate dehydrogenase levels in patients with liver cirrhosis. Hepatol Res. 2002;22:174-179.

19. Roessler M, Rollinger W, Mantovani-Endl Let al. Identification of PSME3 as a novel serum tumor marker for colorectal cancer by combining two-dimensional polyacrylamide gel electrophoresis with a strictly mass spectrometry-based approach for data analysis. Mol Cell Proteomics. 2006;5:2092-2101.

20. Ren H, Du N, Liu G et al. Analysis of variabilities of serum proteomic spectra in patients with gastric cancer before and after operation. World J Gastroenterol. 2006;12:2789-2792.

21. Wang TH, Chao A, Tsai CL et al. Stress-induced phosphoprotein 1 as a secreted biomarker for human ovarian cancer promotes cancer cell proliferation. Mol Cell Proteomics. 2010;9:1873-1884.

22. Jmal A, Abdennebi M, Boussen $\mathrm{H}$ et al. [Serum lactate dehydrogenase and its isoenzymes in nasopharyngeal carcinoma in Tunisia]. Tunis Med. 2005;83:218-220.

23. Le Naour F, Misek DE, Krause MC et al. Proteomics-based identification of RS/DJ-1 as a novel circulating tumor antigen in breast cancer. Clin Cancer Res. 2001;7:3328-3335. 
24. Chang YH, Wu CC, Chang KP, Yu JS, Chang YC, Liao PC. Cell secretome analysis using hollow fiber culture system leads to the discovery of CLIC1 protein as a novel plasma marker for nasopharyngeal carcinoma. J Proteom Res. 2009;8:5465-5474.

25. Fujii J, Ikeda Y. Advances in our understanding of peroxiredoxin, a multifunctional, mammalian redox protein. Redox Report. 2002;7:1-8.

26. Yeung DC, Xu A, Tso AW et al. Circulating levels of adipocyte and epidermal fatty acid-binding proteins in relation to nephropathy staging and macrovascular complications in type 2 diabetic patients. Diabets Care. 2009;32:132-134.

27. Cauwe B, Martens E, Van den Steen PE et al. Adenylyl cyclase-associated protein-1/CAP1 as a biological target substrate of gelatinase B/MMP9. Exp Cell Res. 2008;314:2739-2749.

28. Bell LN, Theodorakis JL, Vuppalanchi R et al. Serum proteomics and biomarker discovery across the spectrum of nonalcoholic fatty liver disease. Hepatology. 2010;51:111-120.

29. Ritter M, Buechler C, Boettcher A et al. Cloning and characterization of a novel apolipoprotein A-I binding protein, AI-BP, secreted by cells of the kidney proximal tubules in response to HDL or ApoA-I. Genomics. 2002;79:693-702.

30. Hoyt CS 3rd, Billson FA. Low-carbohydrate diet optic neuropathy. Med J Aust. 1977;1:65-166.

31. Tumani H, Shen G, Peter JB, Brück W. Glutamine synthetase in cerebrospinal fluid, serum, and brain: a diagnostic marker for Alzheimer disease? Arch Neurol. 1999;56:1241-1246.

32. Mohan H, Krumbholz M, Sharma R et al. Extracellular matrix in multiple sclerosis lesions: Fibrillar collagens, biglycan and decorin are upregulated and associated with infiltrating immune cells. Brain Pathol. 2010;20:966-975.

33. Eaton RH, Moss DW. Alkaline orthophosphatase and inorganic pyrophosphatase activities in human serum. Nature. 1967; 214:842-843.
34. Waerner T, Alacakaptan M, Tamir I et al. ILEI: a cytokine essential for EMT, tumor formation, and late events in metastasis in epithelial cells. Cancer Cell. 2006;10:227$-239$.

35. Reynolds JM, Angkasekwinai P, Dong C. IL-17 family member cytokines: regulation and function in innate immunity. Cytokine Growth Factor Rev. 2010; 21:413-423.

36. Bührens RI, Amelung JT, Reymond MA, Beshay M. Protein expression in human non-small cell lung cancer: a systematic database. Pathobiology. 2009;76:277-285.

37. Rho JH, Roehrl MH, Wang JY. Tissue proteomics reveals differential and compartment-specific expression of the homologs transgelin and transgelin-2 in lung adenocarcinoma and its stroma. J Proteome Res. 2009;8:5610-5618.

38. $\mathrm{Li} \mathrm{LS}, \mathrm{Kim} \mathrm{H}$, Rhee $\mathrm{H}$ et al. Proteomic analysis distinguishes basaloid carcinoma as a distinct subtype of nonsmall cell lung carcinoma. Proteomics. 2004;4:3394-3400.

39. Upton MP, Hirohashi S, Tome Y, Miyazawa N, Suemasu K, Shimosato Y. Expression of vimentin in surgically resected adenocarcinomas and large cell carcinomas of lung. AmJ Surg Pathol. 1986;10:560-567.

40. Rubporn A, Srisomsap C, Subhasitanont P et al. Comparative proteomic analysis of lung cancer cell line and lung fibroblast cell line. Cancer Genomics Proteomics. 2009; 6:229-237.

41. Singer S, Malz M, Herpel E et al. Coordinated expression of stathmin family members by far upstream sequence elementbinding protein-1 increases motility in non-small cell lung cancer. Cancer Res. 2009;69:2234-2243.

42. Robert C, Bolon I, Gazzeri S, Veyrenc S, Brambilla C, Brambilla E. Expression of plasminogen activator inhibitors 1 and 2 in lung cancer and their role in tumor progression. Clin Cancer Res. 1999;5:2094-2102.

Submitted: 6 May, 2012

Accepted after reviews: 30 July, 2012 